\title{
Correction to: A novel simulated annealing-based optimization approach for cluster-based task scheduling
}

\section{Esra Celik ${ }^{1}$ (D) Deniz Dal ${ }^{1}$ (D)}

Published online: 9 June 2021

(C) Springer Science+Business Media, LLC, part of Springer Nature 2021

\section{Correction to: Cluster Computing https:// doi.org/10.1007/s10586-021-03275-7}

The original version of this article unfortunately contained a mistake. The sentence below the Table 2 read as "The Gantt chart of the 1st schedule is given in Fig. 3. C Cost Function" instead it should read as "C Cost Function".
The sentence "The Gantt chart of the 1st schedule is given in Fig. 3" must be moved to the end of the section "Mapping 1".

The original article has been corrected.

Publisher's Note Springer Nature remains neutral with regard to jurisdictional claims in published maps and institutional affiliations.

The original article can be found online at https:// doi.org/10.1007/s10586-021-03275-7.

Deniz Dal

ddal@atauni.edu.tr

Esra Celik

esra.celik@atauni.edu.tr

1 Computer Engineering Department, Faculty of Engineering, Ataturk University, 25240 Erzurum, Turkey 